очень раннем возрасте, обычно в 12-14 лет, что напрямую запрещается современным египетским законодательством, тем не менее, семьи обычно игнорируют данные правила. Женят детей на основе договоренности, обговоренной задолго до достижения детьми необходимого возраста, иногда даже задолго до рождения ребят. А местные правоохранительные органы, обязанные защищать права на нормальное детство и неприкосновенность, не производят предписанных им в таких случаях действий, тем самым спуская с рук людям детские свадьбы.

Современные египетские жительницы серьезно настроены на саморазвитие. Они стараются обучиться в хороших университетах страны, профессионально занимаются спортом, отстаивают свои права на неприкосновенность и отделения себя от семьи, как самостоятельной личности. Такие смелые девушки помогают миру обратить внимание развитых стран, а также ООН, на прямые нарушения прав человека в Египте. Некоторым из таких активисток приходят реальные угрозы, для них самих и их семей, происходят приставания и избиения на улицах. После происшествий, заявления жертв не всегда принимаются органами полиции, получается, что в итоге вред принесен, но ответственность за него никто не понесет.

Ещё одной опасностью для жительниц современного Египта являются публичные приставания и реальные случаи изнасилований, которые так и остаются безнаказанными. К тому же, в стране считается, что девушка, идущая против правил общества, в котором она проживает, становится грешницей, а точнее «Ар-раджим», как указано в Коране. По мнению местных жителей, такая девушка заслуживает наказания, несмотря на юридические законы и уголовную ответственность. Как говорят некоторые местные обитатели - «Если девушка совершает грех, Аллах дает своим детям право наказать её».

Многие эксперты по гендерным проблемам утверждают, что именно в Египте и окружающих его странах, условия для жизни женского пола являются наиболее опасными. И происходит это именно из-за устойчивых религиозных и бытовых стереотипов, разрушить которые не спешат не власти, ни местный народ [2]. Но, именно современная смелая молодежь, стремиться к изменению старых порядков и каждых их шаг, каждая акция протестов или девиантное по мнению населения поведение дает надежду, на, возможно не скорое, но уже более возможное равноправие мужчин и женщин, так необходимое для счастливой жизни египетских гражданок.

$$
* * *
$$

1. Турк С.Н. Движение за эмансипацию женщин в Египте (начальный этап; вторая половина ХIX - первая четверть XX в.). Диссертация на соискание ученой степени кандидата исторических наук / Кубанский государственный университет. Краснодар, 2003

2. Турк С.Н. Участие женщин Египта в революции 1919 г. // Общество: философия, история, культура. - 2019. - № 9. - С. 87-89.

3. Турк С.Н., Удодова В.И. Права женщин в Египте: законы и реальность // Социально-гуманитарный вестник. Всероссийский сборник научных трудов. Краснодар, 2019. С. 127-129.

4. Турк С.Н. Феминистское движение в Египте во второй половине XX - начале XXI в.: проблемы и перспективы // Общество: философия, история, культура. 2017. № 2. С. 69-71.

\title{
Фофанова А.Ю., Андреев Д.М. \\ Решение вопросов благоустройства с участием населения (на примере муниципального образования г. Оленегорск с подведомственной территорией Мурманской области)
}

Мурманский филиал РАНХиГС

(Россия, Мурманск)

doi: 10.18411/trnio-10-2021-85

\section{Аннотация}

Авторы статьи рассказывают о рождении города Оленегорск, указывают нормативные акты, регулирующие деятельность органов местного самоуправления г. Оленегорск в сфере благоустройства. 
Заслуживает внимания материал авторов об организации и проведении мероприятий среди населения по выбору территории для участия муниципального образования г. Оленегорск во Всероссийском конкурсе лучших проектов создания комфортной городской среды.

Цель написания статьи - показать взаимосвязь между активным участием населения (ролью мнения жителей) и принятием окончательных решений органами местного самоуправления по вопросам в сфере благоустройства и создания комфортной городской среды в муниципальном образовании г. Оленегорск с подведомственной территорией.

Задачи для написания статьи: изучение нормативных документов различного уровня, определяющих вопросы благоустройства в муниципальном образовании; наблюдение за деятельностью органов местного самоуправления в муниципальном образовании в сфере благоустройства и создания комфортной городской среды; определение пожеланий населения г. Оленегорск с подведомственной территорией в процессе голосования по положениям концепции благоустройства общественных территорий.

Решение поставленных в статье задач осуществлялось на основе применения общенаучных методов исследования в рамках сравнительного, логического и статистического анализа, а также посредством изучения разнообразных источников информации, анализ полученных сведений, описательного метода, социологического наблюдения и пр.

Научная новизна - до настоящего времени не были рассмотрены проблемы в сфере благоустройства г. Оленегорск с подведомственной территорией.

Практическая значимость исследования - приведенные примеры проведенных мероприятий по благоустройству в 2020 г. и о планируемых мерах в 2021 г. в г. Оленегорск с подведомственной территорией могут быть использованы в работе администраций других муниципальных образований в РФ.

Ключевые слова: благоустройство, выбор территории, Общественная комиссия, комфортная городская среда, проект, анкетирование, предложения, голосование.

\section{Abstract}

The authors of the article talk about the birth of the city of Olenegorsk, indicate regulatory acts governing the activities of local governments in the field of improvement.

The authors' material on the organization and holding of events among the population on the choice of territory for the participation of the municipality of Olenegorsk in the All-Russian competition of the best projects for creating a comfortable urban environment deserves attention.

The purpose of the article is to show the relationship between the active participation of the population (the role of the opinion of residents) and the adoption of final decisions by local authorities on issues in the field of improvement and creation of a comfortable urban environment in the municipality of Olenegorsk with a subordinate territory.

Tasks for writing the article: studying regulatory documents of various levels that determine the issues of improvement in the municipality; monitoring the activities of local authorities in the municipality in the field of improvement and creation of a comfortable urban environment; determining the wishes of the population of Olenegorsk with a subordinate territory in the process of voting on the provisions of the concept of improvement of public territories.

The solution of the tasks set out in the article was carried out on the basis of the use of general scientific methods of research in the framework of comparative, logical and statistical analysis, as well as through the study of various sources of information, the analysis of the obtained information, the descriptive method, sociological observation, etc.

Scientific novelty - to date, problems in the improvement of the city of Olenegorsk with subordinate territory have not been considered.

The practical significance of the study is given examples of the improvement measures carried out in 2020 and about the planned measures in 2021 in Olenegorsk with a subordinate 
territory can be used in the work of the administrations of other municipalities in the Russian Federation.

Keywords: improvement, choice of territory, Public Commission, comfortable urban environment, project, questionnaire, proposals, voting.

Город Оленегорск расположен в центре Кольского полуострова Мурманской области. Своим рождением он обязан большому железорудному месторождению, открытому в 1932 г., а названием - неподалеку расположенной железнодорожной станцией - Оленья. Так, 27.03.1957 г. рабочий поселок был преобразован в город Оленегорск. [1] Сегодня этот город один из центров муниципального образования с населением 20364 чел. Он включен в категорию моногородов, его основным предприятием является Оленегорский ГОК, разрабатывающий железорудное месторождение.

Благоустройство и озеленение городских территорий является одной из важнейших сфер деятельности органов местного самоуправления, обеспечивающих создание здоровых, целесообразных, благоприятных условий жизни населения этого города.

Администрация города Оленегорска, руководствуясь Федеральным законом от 06.10 2003 г. № 131-Ф3 «Об общих принципах организации местного самоуправления в Российской Федерации» [2], Уставом муниципального образования [3] и программой «Формирование комфортной городской среды на 2018 - 2022 гг.» муниципального образования город Оленегорск с подведомственной территорией» [4] (далее - Программа) проводит активную работу по реализации мероприятий, направленных на благоустройство с целью обеспечения комфортных условий проживания для населения.

Так, дизайн-проекты Программы выставляются на сайте администрации для ознакомления, осуществляется прием предложений от граждан, затем проводят общественные обсуждения.

В 2019 г. органы местного самоуправления провели ряд мероприятий среди населения по выбору территории для участия муниципального образования город Оленегорск с подведомственной территорией во Всероссийском конкурсе лучших проектов создания комфортной городской среды. Предложения от населения поступали путем проведения анкетирования на страничке группы Главы администрации города в социальной сети ВКонтакте, приема предложений в урны для голосования в общественных местах - МФЦ «Полярная звезда», «МУК ЦКиД «Полярная звезда», в городской библиотеке, приема обращений в МКУ «Управление городского хозяйства», через виртуальную приемную администрации города Оленегорска.

Населением, для участия во Всероссийском конкурсе лучших проектов, были предложены следующие общественные территории:

- благоустройство сквера «Молодежный»;

- благоустройство сквера «Надежда»;

- благоустройство территории городского парка «Горняк» (вокруг озера Комсомольское);

- $\quad$ благоустройство сквера Космонавтики и прилегающих территорий.

Подготавливая документы к конкурсу Общественная комиссия, учитывая финансовые и социальные возможности муниципального образования, провела оценку всех предложенных общественных территорий по таким критериям, как: реализуемость мероприятий; общественная значимость и популярность территории среди большинства населения, ее культурный потенциал; обеспечение сохранности результатов благоустройства; взаимосвязь с другими проектами; пешеходная доступность; востребованность территории гражданами с ограниченными возможностями (инвалидами, маломобильным населением); площадь благоустройства.

На заседании 16.07.2019 г. Общественная комиссия решила выбрать для участия во Всероссийском конкурсе благоустройство сквера Космонавтики и прилегающих 
территорий, как наиболее соответствующее критериям отбора и с наибольшими шансами, в сравнении с другими территориями.

Позднее, 02.08.2019 г., прошел семинар в ЦКиД «Полярная звезда» с участием 35 активных горожан, разделившихся на 8 групп, каждая из которых представила недостатки развития и ценности территории проектирования сквера Космонавтики. Бурное обсуждение позволило выявить проблемы проектируемой территории, а именно: нет активности территории для молодежи и детей; отсутствие освещения; запущенность территории; отсутствие ландшафтных композиций; неудачная пешеходная доступность; недоступная территория для инвалидов; территория, заросшая густым лесом и др.

Заслуживает внимания тот факт, что участники определили ценности территорий проектирования и что, по их мнению, подлежит обязательному сохранению: космическая тема; горняцкая тема; памятник В.И. Ленину; березы - символ нашей Родины; комплексность, ансамблевое благоустройство в рамках цепи четырех скверов.

Общественная комиссия муниципального образования, после проведенного семинара, на заседании 12.08.2019 г., сочла целесообразным мнение горожан и решила рекомендовать разработку не менее двух вариантов концепций развития территории проектирования для предоставления населению права выбора наиболее востребованного варианта большинством голосующих, а за основу концепции развития территории проектирования предусмотреть:

- детскую и спортивную площадки, с учетом возрастных особенностей развития детей, доступные для инвалидов и маломобильных групп населения;

- сцену и амфитеатр для проведения уличных массовых культурных мероприятий;

- мероприятия по реорганизации паркового пространства, рационального размещения автобусных остановок, пешеходных переходов для граждан;

- варианты ландшафтного дизайна территории проектирования с учетом размещения цветников, альпийских горок и т.д.;

- сохранение имеющихся на территории памятников и памятных камней, установленных при закладке скверов;

- установку арт-объектов, световых инсталляций.

Голосование по концепциям благоустройства общественных территорий муниципального образования город Оленегорск с подведомственной территорией для участия во Всероссийском конкурсе было проведено 08.09.2019 г. В общественном голосовании приняло участие 3618 граждан. Число опросных листов - 3618, недействительных опросных листов - 11, число действительных опросных листов - 3607. За благоустройство общественной территории № 1 было 2089 голосов, а за благоустройство общественной территории № 2 - 1518 голосов.

Проект благоустройства общественной территории сквера «Молодежный» г. Оленегорска в 2019 г. стал финалистом Всероссийского конкурса лучших проектов создания комфортной городской среды.

Одним из приоритетных проектов муниципального образования город Оленегорск с подведомственной территорией - это «Формирование комфортной городской среды». В рамках реализации которого в 2020 г. были проведены следующие мероприятия:

благоустройство сквера «Молодежный» в городе Оленегорск позволило замостить дорожки тротуарной плиткой, установить МАФ, спортивное оборудование, провести озеленение, установить парковые светильники. Этот проект был финалистом Всероссийского конкурса лучших проектов создания комфортной городской среды, сумма расходов на него составила 60000 000, 00 руб.;

- осуществлено благоустройство территории и подходов к Памятнику Неизвестному солдату в г. Оленегорске, район озера Комсомольское. Было 
проведено работ на 19800 00,00 руб. - заменены лестницы, поручни, положена тротуарная плитка;

- $\quad$ приведены в порядок дворовые территории по адресам: улица Пионерская, д. 4, д. 6, д. 8 (на сумму 7012 936,11 руб.), улица Строительная, д. 53, д. 53А (на сумму 11198 063,00 руб.), д. 45 (на сумму 2792 358,04 руб.), а именно: отремонтированы дворовые проезды, организованы парковочные места, установлены ботовые камни.

В декабре 2020 г. министр градостроительства и благоустройства Мурманской области Мария Гаврилова с рабочей поездкой посетила город Оленегорск. Она проверяла реализацию проектов 2020 г. и обсудила с местной администрацией перспективы реализации работ по благоустройству в 2021 г. Ведь город Оленегорск стал победителем 1 этапа Всероссийского конкурса лучших проектов по благоустройству в малых городах и исторических поселениях в 2020 г., который проводился в рамках приоритетного национального проекта «Жилье и городская среда». Федеральное финансирование в 2021 г. кардинально изменит сквер Космонавтики. Проект предусматривает устройство проездов, дорожек, детских и спортивных площадок, будут установлены скамейки и арт-объекты. Появится новое освещение и сцена у ДК «Горняк для проведения городских праздничных мероприятий. Будет отреставрирован памятник «Покорителям Космоса».

В рамках федерального проекта «Формирование комфортной городской среды», государственной региональной программы Мурманской области «Формирование современной городской среды» в г. Оленегорске планируется благоустройство территории зоны отдыха на ул. Мира, д. 33, д. 37, рядом со школой-интернатом и общеобразовательной школы № 15. К территории благоустройства примыкает многоквартирный дом № 37 по ул. Бредова с магазином, доступным для жителей микрорайона, а зона отдыха с лавочками удобна для пенсионеров. [5]

Кроме того, в 2021 г. планируется установка игрового оборудования на трех детских площадках города, создание спортивной и скейт-площадки в сквере «Горняк».

Мероприятия по благоустройству меняют облик города. Эти изменения положительно встречает население, и оно активно участвует в мероприятиях по их планированию, отбору дворовых территорий, муниципальных территорий общего пользования для включения в муниципальную программу. Практика показала, что активная жизненная позиция населения способна реально влиять на принятие окончательных решений в сфере благоустройства. Ремонт дворовых территорий, озеленение и благоустройство скверов, в значительной степени, определяют состояние микрорайонов, ведь без этого город не может носить комплексный характер и эффективно влиять на повышение качества жизни населения.

$$
* * *
$$

1. Официальный сайт органов местного самоуправления муниципального образования город Оленегорск с подведомственной территорией.URL: https://olenegorsk.gov-murman.ru/ (дата обращения: 05.08.2021)

2. Об общих принципах организации местного самоуправления в Российской Федерации : федер. закон от 06.10.2003г. № 131-Ф3 (ред. от 29.12.2020). Доступ из СПС КонсультантПлюс. URL: http://www.consultant.ru/document/cons_doc_LAW_44571/ (дата обращения: 06.08.2021)

3. Устав муниципального образования г. Оленегорск Мурманской области с подведомственной территорией : утв. решением Оленегорского городского Совета от 02.07.2010 № $01-44$ рс. (ред. от 24.04.2018).Официальный сайт г. Оленегорска с подведомственной территорией URL: https://olenegorsk.govmurman.ru/vlast/sovet-deputatov/ustav.php (дата обращения: 08.08.2021)

4. Формирование комфортной городской среды на 2018 -2022 гг. муниципального образования город Оленегорск с подведомственной территорией : постановление администрации г. Оленегорска Мурманской области от 20.10.2017. № 452. Официальный сайт г. Оленегорска с подведомственной территорией URL: https://olenegorsk.gov-murman.ru/city/socs/formsovgor/ (дата обращения: 08.08.2021)

5. В 2021 г. в Оленегорске будет реализован проект по благоустройству - победитель Всероссийского конкурса. Официальный сайт Правительства Мурманской области. Новости 14.12.2020 URL: https://govmurman.ru/info/news/386005/ (дата обращения: 11.08.2021) 